\title{
DIELECTRIC PROPERTIES OF POTATO TUBERS RELATED TO STORAGE CONDITIONS
}

\author{
Soliman N. Soliman ${ }^{1}$ and Azhar El-WershEl-Sayed ${ }^{2}$
}

ABSTRACT

The objective of this work is to study the dielectric properties of potato tubers asa criteria for predicting of freshnessfor each of fresh and storage commodity under traditional (Nawala) and cold conditions. Dielectric measurementswere measured using LCZ meter,andwere conducted on fresh and stored tubers, for measuring of capacitance (Farad, f), and conductance (Siemens, S) over a range of frequencies from 10 to 1000 $\mathrm{kHz}$. The measured value were used to calculate permittivity $(\mathrm{f} / \mathrm{m})$, conductivity $(S / m)$, relative permittivity, complex permittivity (S.sec/f), complex conductivity (f/m.sec) and dissipation factor or "loss tangent" (tan $\delta$ ) of potato tuber.

The capacitance, relative permittivitydecreases rapidly with increasing frequency.Dissipation factor Tan ( $\delta$ ) decreases gradually with increasing the storage time. Complex permittivity and Complex conductivity were decreases with the increases of the storage time.

The quality factor $Q$ was expressed as a percentage value of the ratio between conductance at high frequency to that at low frequency $(G H / G L)$ for the stored tissue to that for the fresh tissue to indicate the degree of freshness. The quality factor $Q$ decreases with the increasing ofstorage time, storage temperature and storage load stressand isa fairly goodindication of the loss of freshness. The storage ages of potatoes were predictedwith very sensitive equation using the quality factor, tuber weight and storage temperature.

\section{INTRODUCTION}

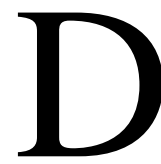
ielectric properties of agricultural materials and products are finding increasing application, as new technology is adapted for use in agricultureand related industries. These properties are important in explaining or in predicting the interaction of materials with environmental parameter.

1- Prof. of Food Engineering, Faculty of Agriculture, Alex University.

2- Researcher at Agricultural Engineering Research Institute, Agricultural Research Center, Ministry of Agriculture. 
Freshness is one of the most important factors, which determine quality of food (Babbitt 1981, Sakaguchi and Koik, 1992). Various sensory methods have been used to assess the freshness. Electronic methods have the advantage of speed, they are non-destructive and are objective (Babbitt, 1981 and Sakaguchi and Koik, 1992) improved methods for rapidly sensing quality factors of fruits and vegetables, such as moisture content, maturity, defects and blemishes, would be helpful in the harvesting, sorting, and packing operations for these commodities. Rapid sensing techniques that can be adapted on-line processes, such as sorting and grading, can simultaneously save labor costs and provide improvement in the uniformity and quality of the products (Nelson et al, 1995).

Dielectric properties can be defined in terms of complex permittivity (ee). The complex permittivity (e $\varepsilon)$ is composed of a real part (e $\varepsilon^{\prime}$, relative dielectric constant) and an imaginary part (e $\varepsilon^{\prime \prime}$, relative dielectric loss factor) and is given by the equation (Saltiel and Datta, 1999):

$$
\mathrm{e} \varepsilon=\mathrm{e} \varepsilon_{\mathrm{o}}\left(\mathrm{e} \varepsilon^{\prime}-\mathrm{je} \varepsilon^{\prime \prime}\right)
$$

Where: $\mathrm{j}=(-1)^{0.5}$ and $\varepsilon_{\mathrm{o}}$ is the permittivity of free space $\left(8.86 \times 10^{-12}\right.$ $\mathrm{F} / \mathrm{m})$, ( $\mathrm{j} \omega)$ was changed to (je $\left.\varepsilon^{\prime \prime}\right)$. Loss tangent $(\tan \delta)$, a parameter is the ratio of dielectric loss factor $\left(e \varepsilon^{\prime \prime}\right)$ to the dielectric constant $\left(e \varepsilon^{\prime}\right)$. A product with a higher loss tangent will heat faster under microwave field as compared to a product with a lower loss tangent (Nelson and Datta, 2001).

The relative permittivity $\mathbf{e} \boldsymbol{\varepsilon}^{\prime}$ and conductivity e $\boldsymbol{\sigma}$ of a material are, respectively, the dipole and current densities induced in response to an applied electric field of unit amplitude. The significance of these quantities were illustrated by considering an ideal parallel plate capacitor, whose plates have surface area $A$ and separation $d$, the capacitance $C$ and conductance $\mathrm{G}$ of the capacitor are then:

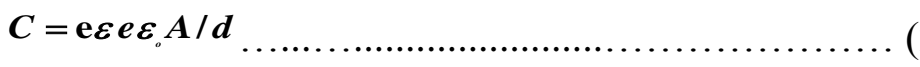

$$
\begin{aligned}
& G=e G A / d
\end{aligned}
$$

At radian frequency $\omega$, the admittance $\mathrm{Y}$ of the capacitor can be written:

$$
Y=(G+j \omega C)
$$




$$
\begin{aligned}
& Y=\left(e \sigma+j \omega \mathrm{e} \varepsilon \mathrm{e} \varepsilon_{o}\right) \frac{A}{d}
\end{aligned}
$$

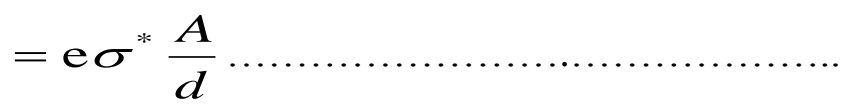

$$
\begin{aligned}
& =J \omega \mathrm{e} \varepsilon^{*} \mathrm{e} \varepsilon_{o} \frac{A}{d}
\end{aligned}
$$

Where: $\mathrm{C}$ (farad), is the capacitance and $\mathrm{G}$ (siemens) is the conductance of the capacitor between the two measuring blades. $A\left(\mathrm{~m}^{2}\right)$ is the surface area of the electrode, (d)is the separation distance between the two blades per meter, $\left(\mathbf{e} \varepsilon^{\prime}\right)$ the relative permittivity, $\left(\mathbf{e} \varepsilon_{0}\right)$ the permittivity of vacuum $\left(8.85 * 10^{-12} \mathrm{~F} / \mathrm{m}\right)$, and $(\mathbf{e} \sigma)$ the electrical conductivity (Siemens $\left./ \mathrm{m}\right) . \mathrm{j}=$ $(-1)^{1 / 2},\left(\right.$ e $\sigma^{*}=\mathrm{e} \sigma+\mathrm{j} \omega$ e $\left.e \mathrm{e} \varepsilon_{\mathrm{o}}\right)$ is the complex conductivity, and $\left(\varepsilon^{*}=\varepsilon-\right.$ $\mathrm{j} \sigma / \omega \varepsilon \mathrm{c})$ is the complex permittivity.

In usual notation $\varepsilon^{*}=\mathrm{e} \varepsilon^{\prime}-\mathrm{je} \varepsilon^{\prime \prime}$ where $e \varepsilon^{\prime \prime}$, is the loss and $\tan \left(\mathrm{e}_{\varepsilon} " / \mathrm{e}_{\varepsilon}^{\prime}\right)$ is the loss tangent. Typically; forsoft tissues at low frequencies, $\left(\right.$ e $\sigma>\omega e \varepsilon^{*}$ e $\left.\varepsilon_{o}\right)$ (Polk and Postow 1996, Joseph and Bronzino, 1995).

The objective of this research is to study the dielectric properties of Lady Rosetta potato tubers variety as a criteria for predicting of potato freshness for each of fresh and storage commodity under traditional (Nawala) and cold conditions.

\section{MATERIALS AND METHODS}

The samples of two fresh potato varieties "Lady Rosetta" which was planted under sand and black soils, each of 500 kilograms were provided from DaltexCompany in Kafr El-Zaiat.

The fresh potato tubers were manually harvested carefully by hand, cleaned from soiland the damage tubers were excluded manually, and transported in the same day to the laboratory of food engineering faculty of agriculture Alexandria University.

The selected tubers from each size were numbered for preparation and recording the physical measurements, including tuber mass, dimension (length, width and thickness), volume, bulk and particle density, surface area, respiration rate, moisture content and sugar contents which were measured according to Mohsenin1986..

The potato tubers were classifieds into three different size small "tubers 
mass of 70 to $<100 \mathrm{~g}$ ", medium "tubers mass of 100 to $<130 \mathrm{~g}$ " and large "tubers mass of $\geq 130 \mathrm{~g}$ ", and The tuber dimensions were measure with an accuracy of $0.01 \mathrm{~mm}$.

The traditional storage chamber (Al-Nawalla)andrefrigeration chamber at $8 \mathrm{C}^{\mathrm{O}}$ and $85 \%$ relative humiditywere used for potato storage. The curing treatments of potatoes carriedat $15 \mathrm{C}^{\mathrm{o}}$ and $90 \%$ relative humidity for 15 days before storage.

The storage potatoes conductedat three levels of static pressure "0.0, 2.44 and $4.87 \mathrm{kPa}$, which was exerted on the top of the potato cage. The amount of 36 storage treatments including six potato samples which were subjected for 6 storage conditions were done in five replicates.

\subsection{Measurements of Dielectric Properties}

Dielectric measurements conducted in the Institute of Graduate Studies and Research, Alexandria University using LCZ Meter Model 4277A, figure (1). The meter designed to measure the capacitance and conductance of plant and animal tissues, equivalent series resistance, impedance magnitude and phase of electronic components and devices. Its built-in test signal source covers the frequency range of $10 \mathrm{KHz}$ to $1000 \mathrm{KHz}$ and provides 701 spot frequencies. Test frequency resolution is $100 \mathrm{~Hz}$ (maximum), and frequency accuracy is $\pm 0.01 \%$ of the selected spot frequency. Spot frequencies selected were $10 \mathrm{KHz}, 100 \mathrm{KHz}$, and $1000 \mathrm{KHz}$.Test signal level is selectable at $1 \mathrm{~V}_{\text {ras }}(\mathrm{HIGH})$ or $20 \mathrm{~m} \mathrm{~V}$ rms (LOW). The 4-tenninal pair configuration provides a basic measurement accuracy of $0.1 \%$ overawidemeasurement range. The samples of potato tubers connected to the meter by means of an electrode. The electrode consists of two parallel blades knife-edge electrode, which used to allow easy insertion of the electrodes inside the potato tuber tissue. The area of each side is equal to $1.35 \mathrm{~cm}^{2}$ and the two parallel blades fixed on two opposite surface of a Plexiglas cylinder of $1 \mathrm{~cm}$ diameter and $1 \mathrm{~cm}$ height as shown in (Figure1).

Capacitance (C) and conductance (G) measured by LCZ meter over a frequency range from $10 \mathrm{kHz}$ to $1000 \mathrm{KHz}$. The measured values used to calculate permittivity and conductivity of potato tubers at time intervals during a long storage time. The relative dielectric permittivity (eغ') and 
conductivity (eб) are calculated using equations $(2,3)$ Polk and Postow, 1996.

The imaginary part of complex permittivity (e $\left.\varepsilon^{\prime \prime}\right)$ and conductivity $(\mathbf{e} \sigma ")$ were calculated according to the relation (Irimajiriet al, 1987, Asamiet al, 1988).

$$
\begin{gathered}
e \varepsilon^{\prime \prime}=\left(e \sigma-e \sigma_{L}\right) / 2 \pi f e \varepsilon_{0} \ldots \ldots \ldots \ldots . . . .(8) \\
e \sigma^{\prime \prime}=2 \pi f e \varepsilon_{0}\left(e \varepsilon-e \varepsilon_{h}\right) \ldots \ldots \ldots \ldots . . . .(9)
\end{gathered}
$$

Where $\left(\sigma_{\mathrm{L}}\right)$ is the low frequency limiting conductivity taken at $10 \mathrm{KHz}$, and $\left(\boldsymbol{\varepsilon}_{\mathrm{h}}\right)$ is the high frequency limiting permittivity taken at $1000 \mathrm{KHz}$.

\subsection{Quality factor (Q)}

The ratio of low frequency impedance to high frequency Impedance measured with a wide range a.c. bridge is an indication of the degree of injury to animal and plant tissue (Mohsenin 1986).As it is known conductivity is a reverse of impedance. The ratio between conductivity at high frequency to that at low frequency $\left(\mathrm{G}_{\mathrm{H}} / \mathrm{G}_{\mathrm{L}}\right)$ have a high value for fresh tissue and lower value (approaching zero) for deterioration tissue.

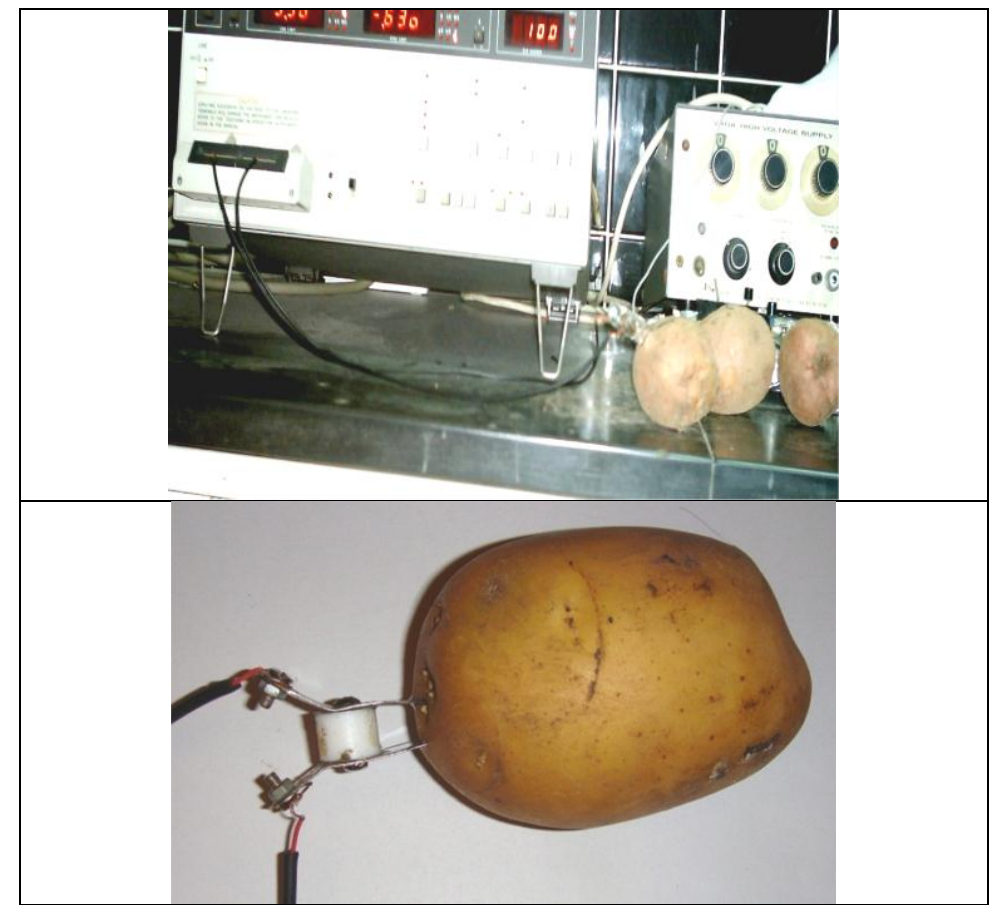

Figure (1) Dielectric apparatus LCZ Meter Model 4227 A 
In the present work, a number $\mathrm{Q}$ was expressed as a percentage value of the ratio $\left(G_{H} / G_{L}\right)$ for the stored sample to that for the fresh sample to indicate the degree of freshness. Thus

$$
Q=\frac{\left(G_{H} / G_{L}\right) \text { stored sample }}{\left(G_{H} / G_{L}\right) \text { fresh sample }} * 100 \ldots \ldots \ldots \ldots
$$

Where: $\left(\mathrm{G}_{\mathrm{H}}\right)$ conductance measured at the higher frequency, $\left(\mathrm{G}_{\mathrm{L}}\right)$ conductance measured at the low frequency.

During all measurements, experimental conditions were kept constant.

\section{RESULTS AND DISCUSSION}

The dielectric properties of fresh and storage potatoes at cold and traditional conditions, storage period, cultivars' (sand and black soils tubers), tuber size and load stress (0.0, 2.44 and $4.77 \mathrm{kPa})$ on dielectric properties were investigated. Sample of five tubers randomized selected from each treatment. 288 potato tubers were measured each run including 36 treatments and 8 replicates.

The measured data of dielectric properties are summarized in two parameters as Capacitance $\mathrm{C}$, microfarad $(\mu \mathrm{f})$ and Conductance $\mathrm{G}$, Siemens (S). The measured parameters are mathematically analyzed into five calculated parameters as Conductivity e $\sigma(\mathrm{S} / \mathrm{m})$, Relative Permittivity e $\varepsilon^{\prime}$, Complex Conductivity e $\sigma^{\prime \prime}(\mathrm{f} / \mathrm{m} . \mathrm{sec})$, Complex Permittivity e $\varepsilon^{\prime \prime}$ (S.sec/f) and Dissipation Factor Tan $(\delta)$.

\subsection{Capacitance}

The dielectric capacitance $(\mathrm{C}, \mu \mathrm{f})$ versus frequency from 10 to $1000 \mathrm{kHz}$ of potato tubers were measured for different storage treatments and are shown graphically in figures (2 and 3 ). The graphs appear that capacitance decreases rapidly with increasing frequency.

The maximum capacitances $(\mu \mathrm{f})$ for all data are at $10 \mathrm{kHz}$ and the minimum values at $1000 \mathrm{kHz}$. The values of capacitances directly proportion with storage time and storage temperature and storage static load stress except at storage time of 200 days, which found that the values of capacitance inversely proportion with static load stress. For sand soil 
cultivars, the values of maximum capacitance of fresh potato were $0.01628 \mu \mathrm{f}$ at $10 \mathrm{kHz}$ and the minimum values was $0.002345 \mu \mathrm{f}$ at 1000 $\mathrm{kHz}$. For storage potato at cold storage and at 120 and 200 days the values of capacitance were 0.0398 and 1.1939 at $0.0 \mathrm{load}$; at $2.44 \mathrm{kPa}$ were 0.03356 and 0.4003 and at $4.87 \mathrm{kPa}$ were 0.0503 and 0.01886 respectively. For traditional storage at 120 days the values of capacitance were 0.0318 at $0.0 \mathrm{load}$; at $2.44 \mathrm{kPa}$ was 0.03078 and at $4.87 \mathrm{kPa}$ was 0.05688. While for black soil cultivars, the values of maximum capacitance of fresh potato were $0.01759 \mu \mathrm{f}$ at $10 \mathrm{kHz}$ and the minimum values was $0.001733 \mu \mathrm{f}$ at $1000 \mathrm{kHz}$. For storage potato at cold storage and at 120 and 200 days the values of capacitance were 0.02957 and 1.4165 at 0.0 load; at $2.44 \mathrm{kPa}$ were 0.06772 and 0.06185 and at $4.87 \mathrm{kPa}$ were 0.05984 and 0.051826 respectively. For traditional storage at 0.0 load and at 120 days the values of capacitance were 0.01755 ; at $2.44 \mathrm{kPa}$ was 0.017875 and at $4.87 \mathrm{kPa}$ was 0.02673 .

Non-linear regression statistical analysis was conducted in order to describe the relationship between capacitance $(\mathrm{C}, \mu \mathrm{f})$ and frequency $(f$ , $\mathrm{kHz}$ ) for all treatments under storage condition. The statistical regression analysis clarify that the power function is the best-fit equation for describing capacitance $\mathrm{C}=a f^{b}$, which a and $\mathrm{b}$ are equation constants, and the coefficient of determination is not less than 0.99 for all cases.

Multiple nonlinear regression analysis were conducted to correlate the measured capacitance $(\mathrm{C}, \mu \mathrm{f})$ as a function of soil types (ST, 1 for sandy and 2 for black soil), frequency ( $f, \mathrm{kHz})$, storage time (D, days), storage temperature $\left(\mathrm{T}, \mathrm{C}^{\mathrm{o}}\right)$, static load stress (SL, $\mathrm{kPa}$ ) and tuber mass $(\mathrm{M}, \mathrm{g}$.$) .$ The step wise regression analysis clarify that the correlation of logarithm capacitance as a function of other parameters under study is the best-fit equation. The statistical regression equations were as follow:

$$
\begin{array}{r}
\operatorname{Ln} C(\mu f)=-1.1176 S T-0.00287 f+0.000785 D-0.0165 T-0.11527 \\
\\
S L-0.01426 M \ldots \ldots . . R^{2}=0.946, S T D E=1.126 \ldots \ldots . .(11)
\end{array}
$$

The equation shows that Ln (Capacitance) negatively affected by each of soils type, storage temperature, static load stress, frequency and tuber mass but directly proportion with storage time. 


\section{Sand Soil}
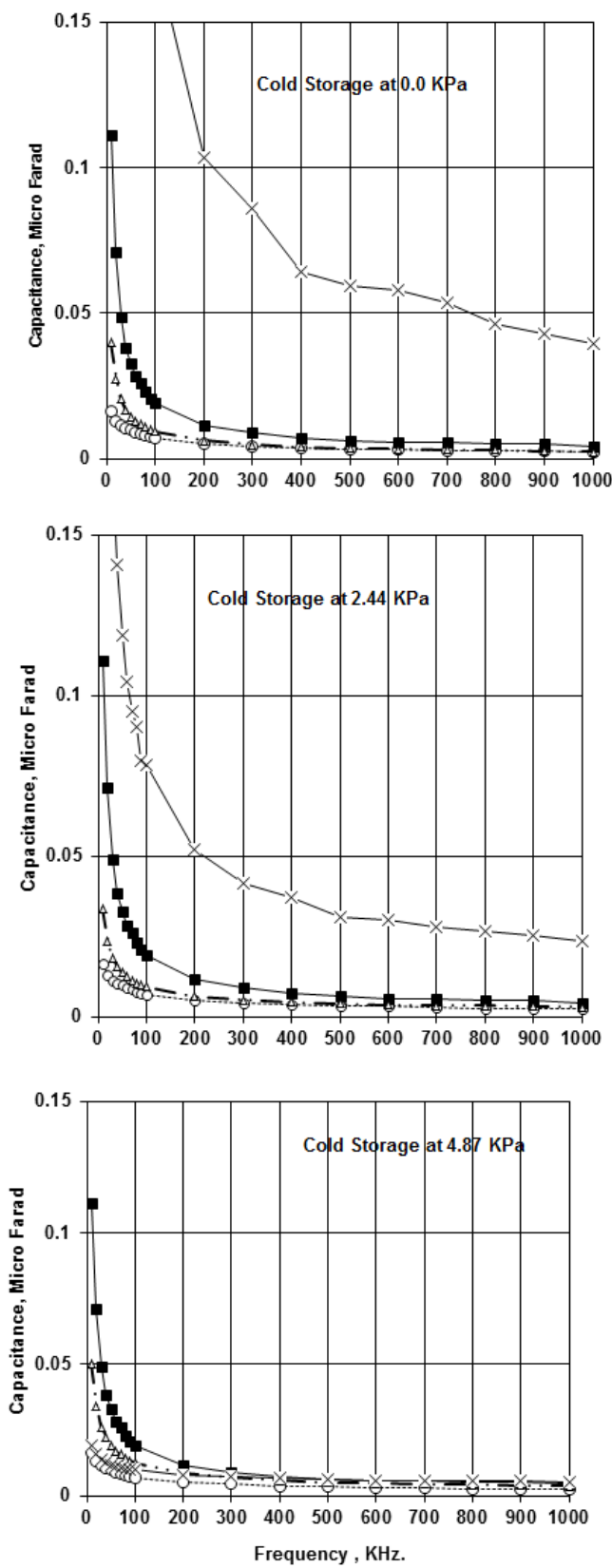

20 Days

$\longrightarrow$ at 120 Days
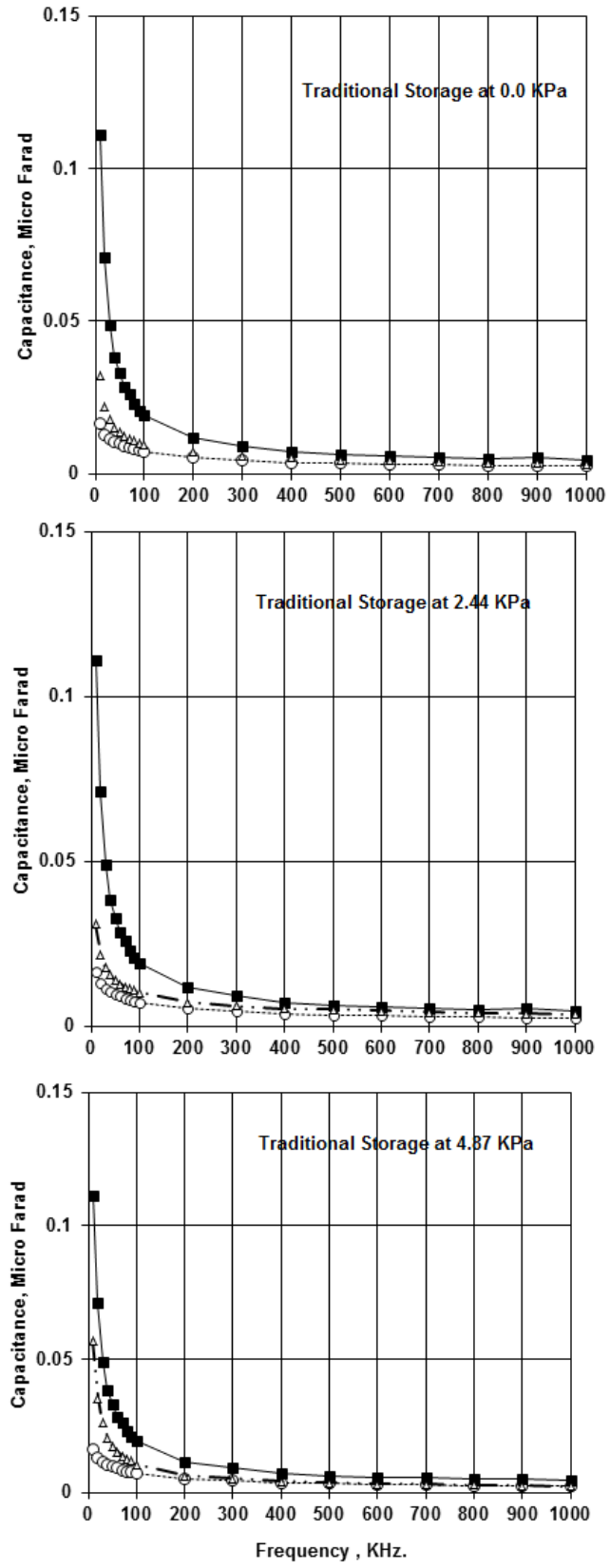

$\ldots-$ at 20 Days $\rightarrow-$ at 60 Days $\longrightarrow$ at 120 Days

Figure (2): Dielectric Capacitance of Stored Sand Soil Potato Tubers. 


\section{Black Soil}
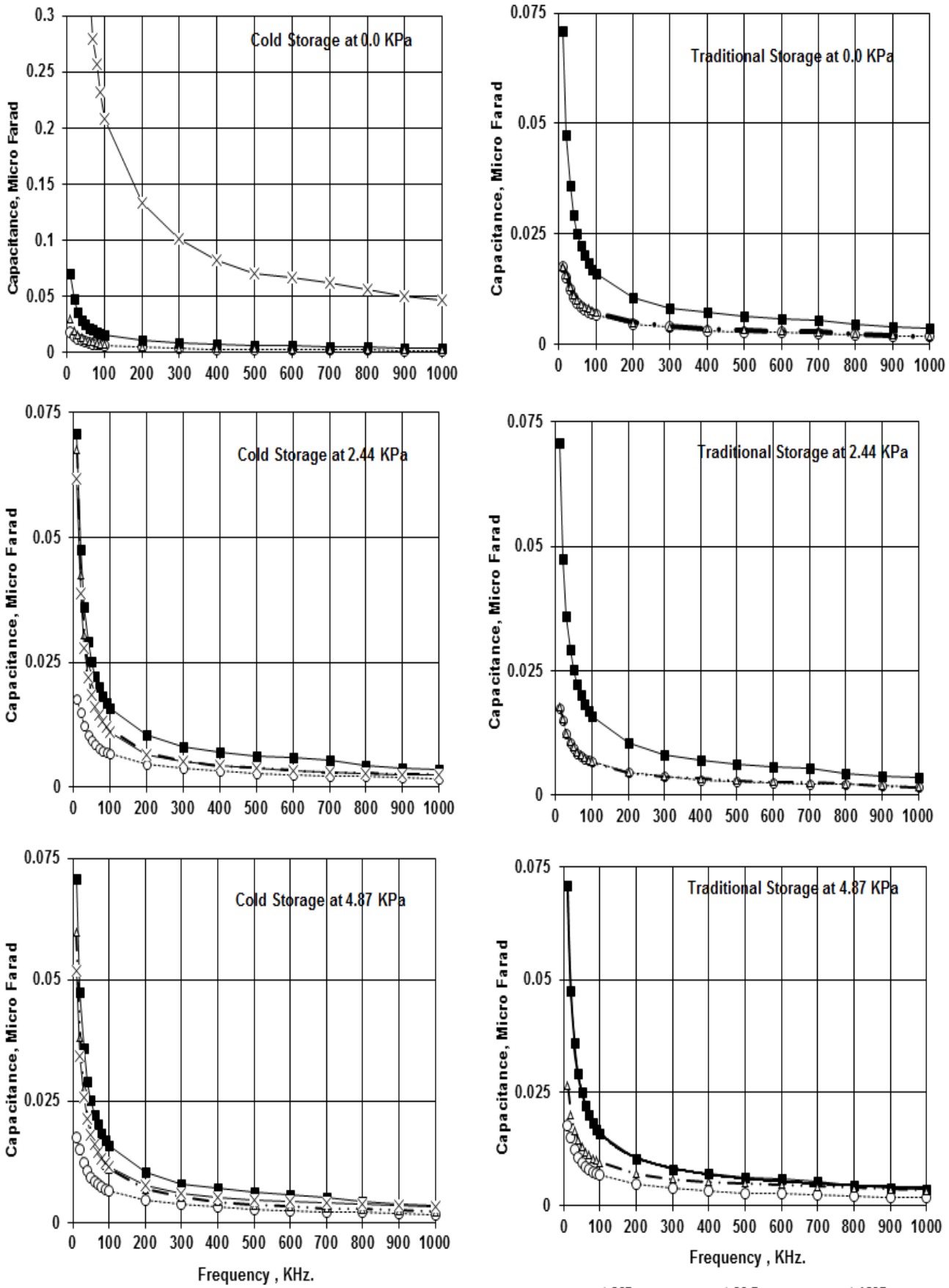

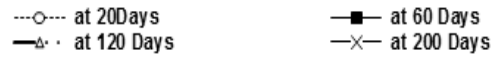$$
\text { ...... at 20Days }- \text { at } 60 \text { Days }-\Delta \cdot \text { at 120Days }
$$

Figure (3): Dielectric Capacitance of Stored Black Soil Potato Tubers. 


\subsection{Conductance}

The dielectric conductance in Siemens, $(\mathrm{G}, \mathrm{S})$ versus frequency of potato tuber at different treatments are shown in figures 4 and 5 as a samples of typical graphs. The graphs appear that conductance increases gradually with increasing frequency.

The maximum conductance $(\mathrm{G}, \mathrm{S})$ for all data are at $1000 \mathrm{kHz}$ and the minimum values at $10 \mathrm{kHz}$. The values of conductance are directly proportion with storage time and storage temperature and storage static load stress except at storage time of 200 day, which found that the values of conductance inversely proportion with static load stress.

For Fresh potato's, the sand soil cultivars have the maximum conductance values of 0.02375 (S) at $1000 \mathrm{kHz}$ and the minimum values of 0.0008167 (S) at $10 \mathrm{kHz}$. For black soil cultivars, the values of maximum conductance were $0.0177015 \mathrm{~S}$ at $1000 \mathrm{kHz}$ and the minimum values was $0.00135 \mathrm{~S}$ at $10 \mathrm{kHz}$.

For cold storage potato, the sand soil cultivars have the maximum conductance value at 120 and 200 days were at $0.0 \mathrm{kPa}$ load 0.02833 and 0.069753 ; at $2.44 \mathrm{kPa}$ were 0.02109 and 0.06274 and at $4.87 \mathrm{kPa}$ were 0.01691 and 0.012849 respectively. For black soil cultivars, the maximum conductance values at 120 and 200 days were at $0.0 \mathrm{kPa}$ load were 0.01929 and 0.10153 ; at $2.44 \mathrm{kPa}$ were 0.0172 and 0.01486 and at 4.87 $\mathrm{kPa}$ were 0.01933 and 0.01502 respectively.

For traditional storage and for the sand soil cultivars at 120 days the maximum conductance values at $0.0 \mathrm{kPa}$ load was 0.03044 ; at $2.44 \mathrm{kPa}$ was 0.027288 and at $4.87 \mathrm{kPa}$ was 0.028267 . For black soil cultivars at 120 days the values of conductance at 0.0 load was 0.02399 ; at $2.44 \mathrm{kPa}$ was 0.023377 and at $4.87 \mathrm{kPa}$ was 0.0172 .

Non linear regression statistical analysis was conducted to describe the relationship between conductance $(\mathrm{G}, \mathrm{S})$ and frequency $(f, \mathrm{kHz})$ for all treatments under storage condition. The statistical regression analysis clarify that the power function is the best-fit equation for describing conductance, $\mathbf{G}=\mathbf{c} f^{\mathbf{d}}$, which $\mathbf{c}$ and $\mathrm{d}$ are equation constants, and the coefficient of determination is not less than 0.98 for all cases. 


\section{Sand Soil}
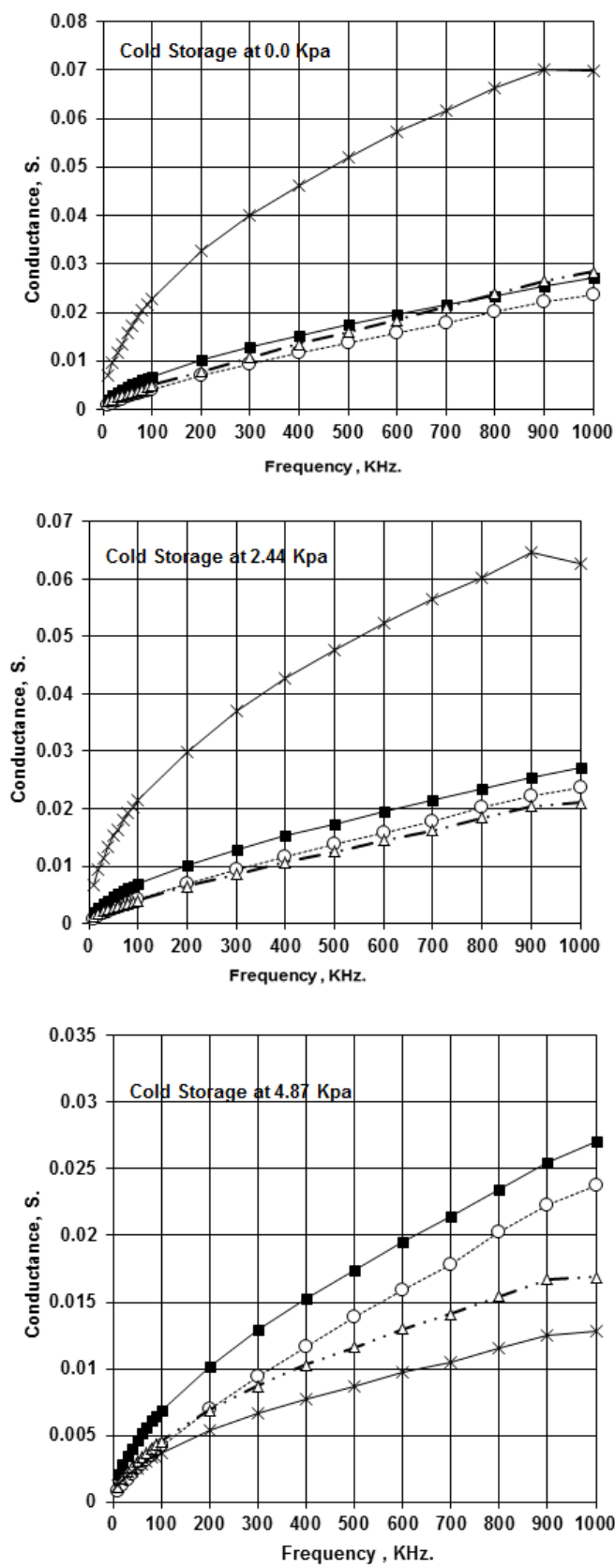

20 Days

$\rightarrow \cdots$ at 120 Days

$\rightarrow-$ at 60 Days

$\leftarrow$ at 200Days stor
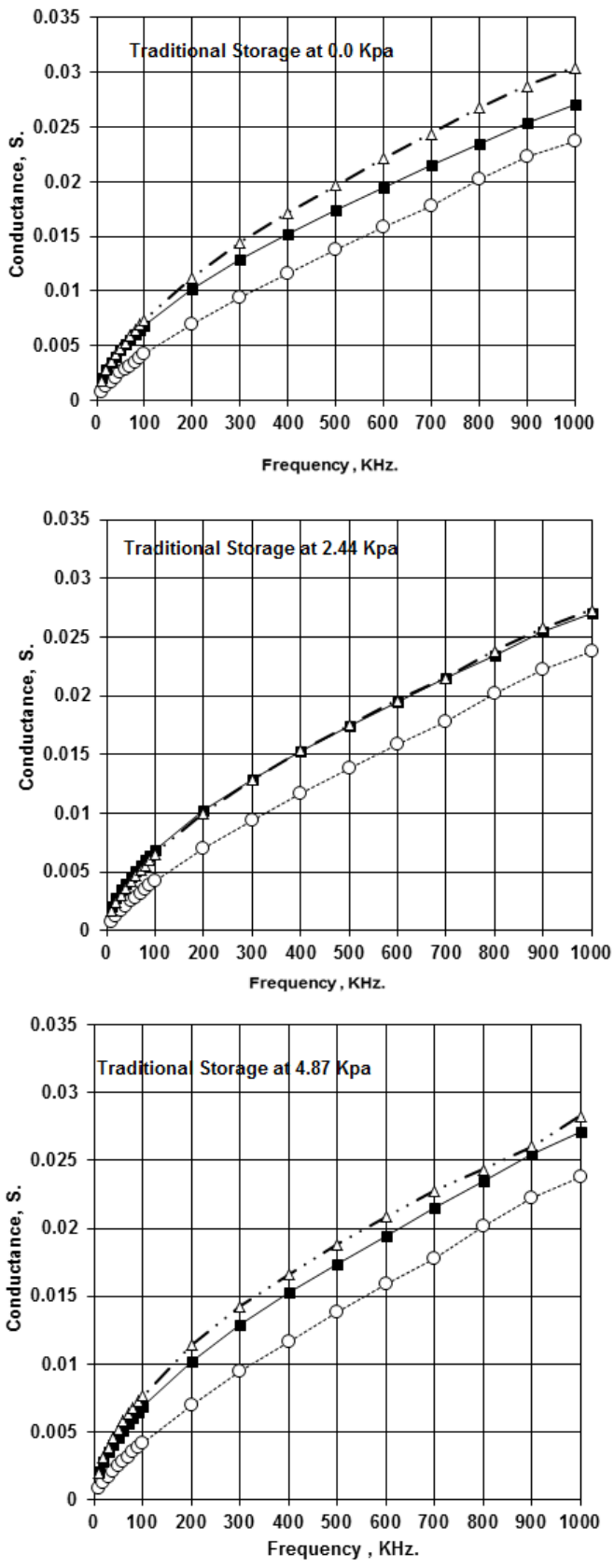

…- at 20 Days $\rightarrow-$ at 60 Days $\triangle \sim$ at 120 Days

Figure (4): Dielectric Conductance of Sand Soil Potato Tubers. 


\section{Black Soil}
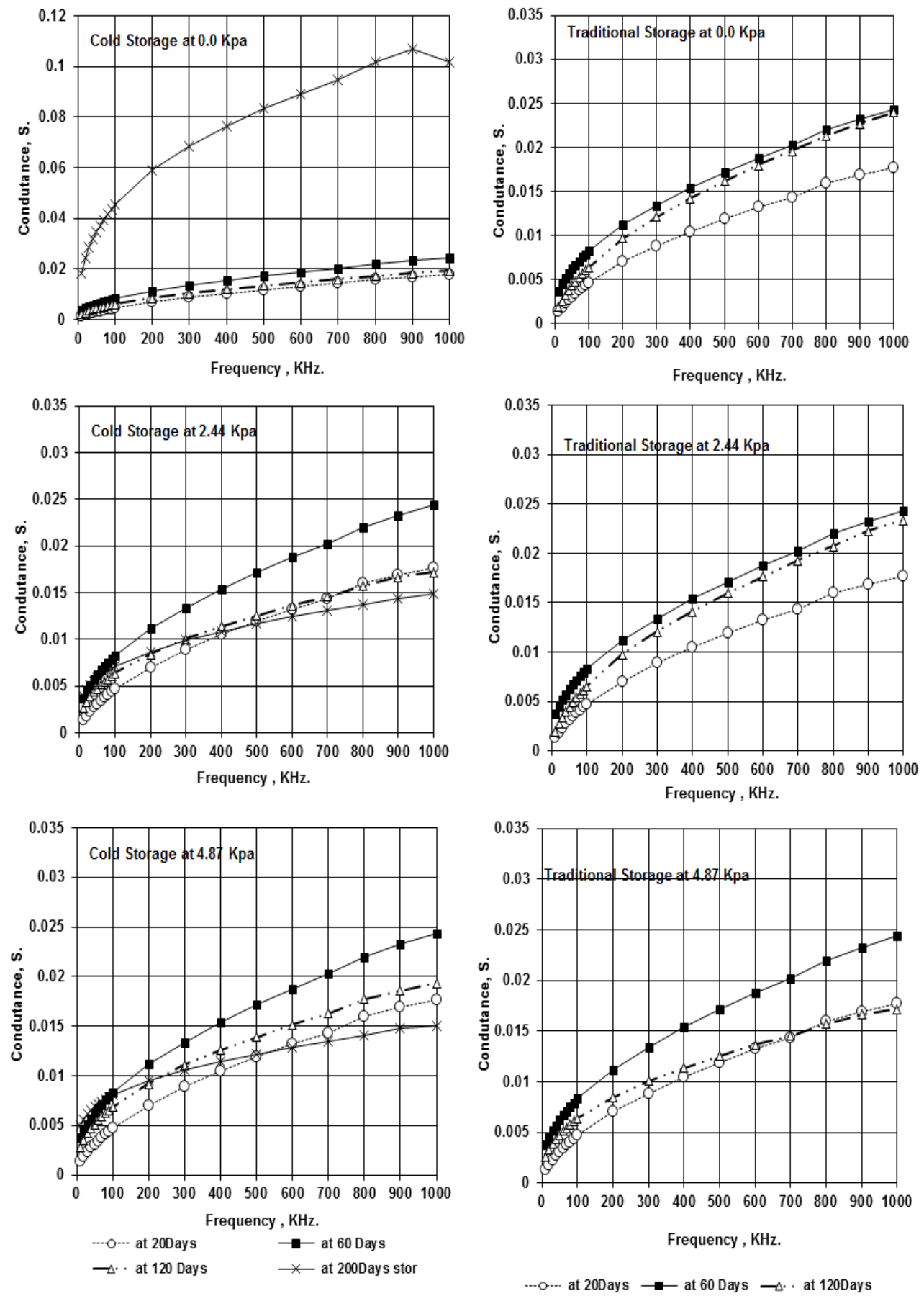

Figure (5): Dielectric Conductance of Black Soil Potato Tubers. 
Multiple linear regression analysis were conducted to correlate the measured conductance $(\mathrm{G}, \mathrm{S})$ as a function of soil types (ST, 1 for sandy and 2 for black soil), frequency ( $f, \mathrm{kHz}$ ), storage time, ( $\mathrm{D}$, days),storage temperature $\left(\mathrm{T}, \mathrm{C}^{\mathrm{O}}\right)$, static load stress $(\mathrm{SL}, \mathrm{kPa})$ and tuber mass $(\mathrm{M}$, g.).The step-wise regression analysis clarify that the correlation of logarithm conductance as a function of other parameters under study is the best fit equation. The statistical regression equation was as shown:

$$
\begin{gathered}
\operatorname{Ln} G(S)=-1.3096 S T+0.00153 f-0.00387 D-0.01621 T-0.1573 S L- \\
0.02101 M \ldots . R^{2}=0.93, S T D=1.297 \ldots(12)
\end{gathered}
$$

The equation shows that Ln $(\mathrm{G})$ negatively affected by each of type of soils, storage time, storage temperature, static load stress and tuber mass but directly proportion with frequency.

\subsection{Quality Factor}

Non-linear regression statistical analysis was conducted in order to describe the relationship between Quality Factor $(\mathrm{Q}, \%)$, and storage time ( $t$, day) for all treatments under storage condition. The regression analysis clarify that the exponential function $\boldsymbol{Q}=\boldsymbol{n} \boldsymbol{e}^{\boldsymbol{x} \boldsymbol{D}}$ is the best-fit equation for describing the quality factor, which $\boldsymbol{n}$ and $\boldsymbol{x}$ are constants and the coefficient of determination for this analysis is not less than 0.90 for all cases.

Multiple linear and non linear regression analysis were conducted to correlate the measured Quality Factor $(\mathrm{Q}, \%)$ as a function of soil types (ST, 1 for sandy and 2 for black soil), storage time (D, days), storage temperature $\left(\mathrm{T}, \mathrm{C}^{0}\right)$ and static load stress $(\mathrm{SL}, \mathrm{kPa})$. The step wise regression analysis clarify that the Quality Factor $(\mathrm{Q}, \%)$ is linearly and inversely proportion with the other parameters under study. The statistical regression equation was shown as follow:

$$
\begin{array}{r}
Q \%=102.4726-0.0224 * S T-0.2219 * D-0.2760 * T-0.6480 * S L \\
\ldots \ldots \ldots . . R^{2}=0.942, S T D E=3.651 \ldots \quad(13)
\end{array}
$$

The quality factor was decreases with the increasing of storage time, storage temperature and storage load stress. The equation shows that the effect of soil type on quality factor is non-significant.

The Quality Factor is inversely proportion with mass loss (ML, \%) during 
the storage period. Mass loss look like other parameters is also inversely proportion with quality factor.

Figure (6) shows the change of quality factor\% and mass losses \% versus storage time for each of sand soil and black soil potatoes. The quality factor $\%$ value decreased with increasing the storage time but the mass losses are increasing. Therefore, it may be assumed that the increasing permeability of the cell walls is caused by the enzymatic and bacterial action that causes deterioration since both give rise to decomposition of proteins. This is a good indication of the loss of freshness.
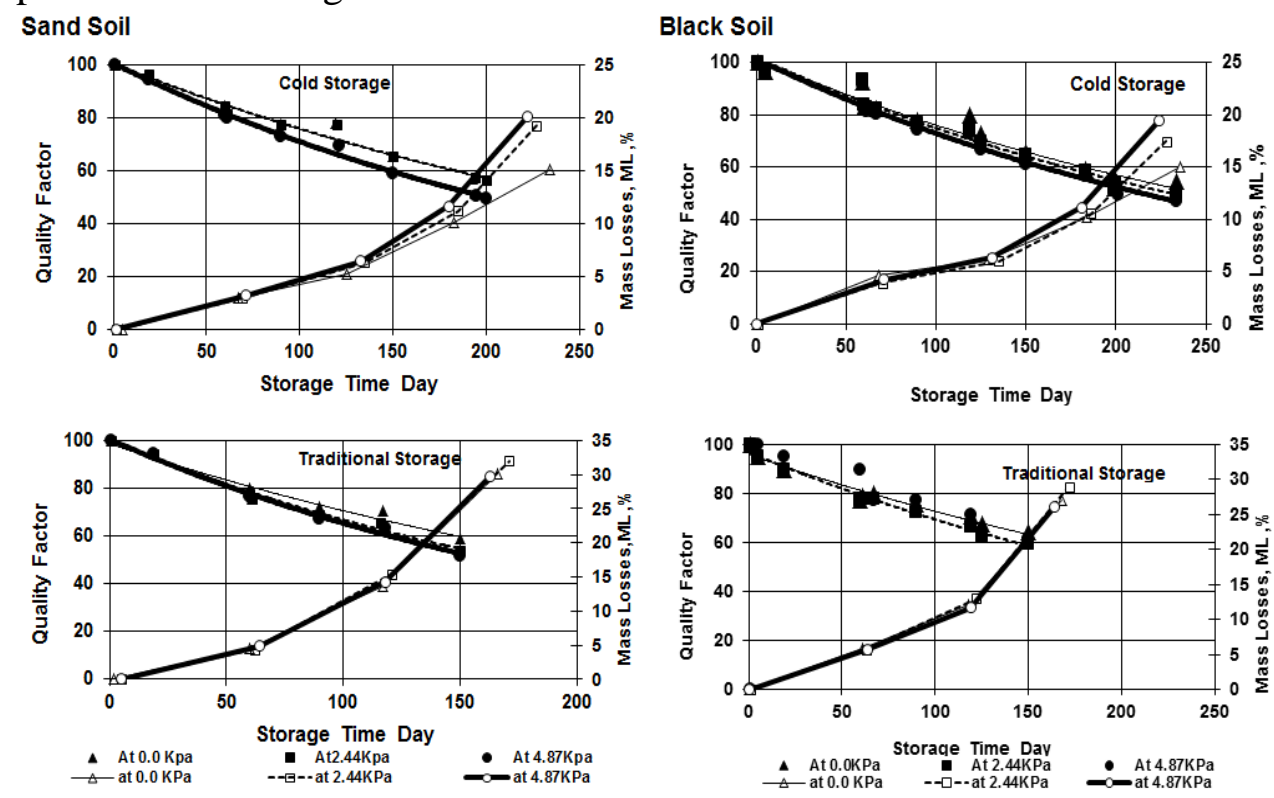

Figure (6): Quality Factors and Mass Losses of Potato Tubers Versus Storage time.

The Quality Factor(Q, \%) shows that the values of $\mathrm{Q}$ are inversely proportion with all parameters. The quality factor decreases with the increasing of storage time, storage temperature and storage load stress. Mass loss look like other parameters is also inversely proportion with quality factor, therefore the quality factor is a good indication of the loss of freshness.

The prediction of storage periodof potato tubers is one of the important demands for potato industry. Multiple regression analysis was conducted to predict the storage time of potato tubers (D, days) as a function of final 
tuber weight $(\mathrm{FW}, \mathrm{g})$, Storage temperature $\left(\mathrm{T},{ }^{\circ} \mathrm{C}\right)$ and quality factor $(\mathrm{Q}$, $\%)$. The statistical regression equations were as follow:

\section{For Sand Soil}

Predicted Storage day, $(D)=463.4417+0.020261 * F W-1.77971 * T$ $.46864 * Q$

For Black Soil

$$
\ldots R^{2}=0.951, S T D E=16.299 . . \quad(14)
$$

Predicted Storage day, $(D)=479.8327+0.04726 * \mathrm{FW}-1.0678 * T$ -

\subsection{6* $Q$}

$$
R^{2}=0.958 S T D E=15.102 . .(15)
$$

Figure (7) presented the predicted storage time, which calculated using equations (14 and 15) versus the actual storage time. The trend line show an inclination of about $45^{\circ}$ that is mean a very sensitive relationship between storage time and quality factor, storage temperature and final weight. This equation can be used for industrial processing of potato tubers.
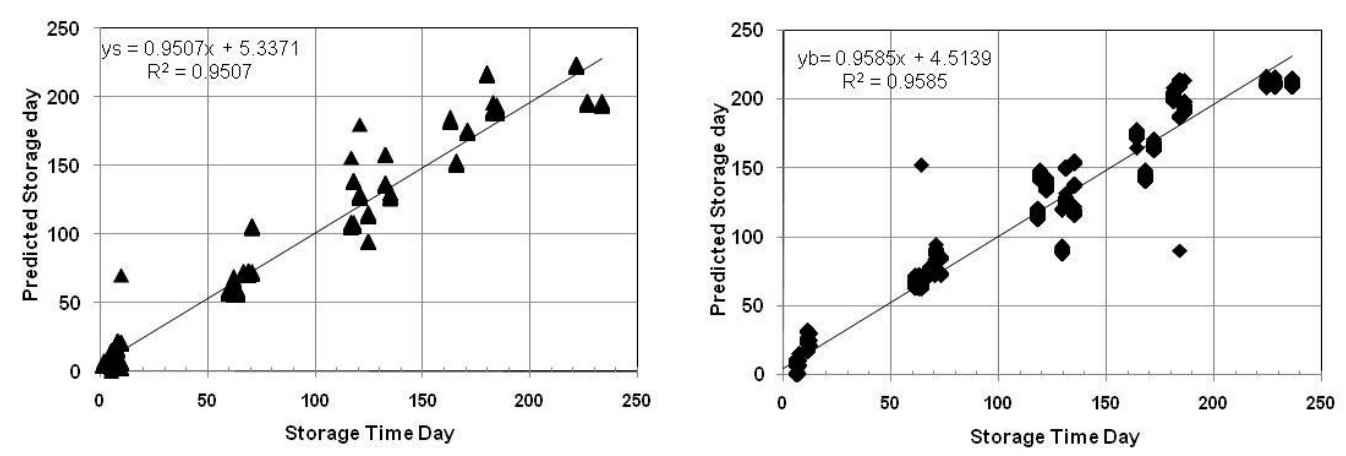

Figure (7): Predicted storage time versus actual storage time of potato tubers.

\section{4- SUMMARY AND CONCLUSION}

The electrical insulation tests were carried out on potato tubers to study the relationship between the storage conditions and the electrical insulation properties, which can be taken as a measure of the freshness of the tubers and as a guide to the quality of the potato tubers. The measurements were used to calculate permeability, conductivity, 
composite permittivity, composite conductivity and Loss tangent for potato above the frequency range of $10-1000 \mathrm{kHz}$. The results showed that the electrical conductivity $\log (\mathrm{G}, \mathrm{S})$ is inversely proportional to storage time, storage temperature, static load stress and tuber weight but directly proportional to the frequency level.

The quality factor $\mathrm{Q}$ was expressed as a percentage value of the ratio between conductance at high frequency to that at low frequency (GH/GL) for the stored tissue to that for the fresh tissue to indicate the degree of freshness. The quality factor $\mathrm{Q}$ decreases with the increasing of storage time, storage temperature and storage load stress and is a fairly good indication of the loss of freshness. The Quality Factor is inversely proportion with mass loss (ML, \%) during the storage period. This is a good indication of the loss of freshness. The statistical analysis appeared a very sensitive relationship between quality factor and each of storage time, storage temperature and final weight. The quality factor equations can be applied in industrial processing for predicting of storage ages of potatoes with a high sensitivity.

\section{REFRENCES}

Asami K, Y. Takahashi and S. Takashima, (1989).Dielectric properties of mouse lymphocytes and erythrocytes .Biochimica et Biophysica Acta, 1010:49-55.

Babbitt J., (1981). Measuring free fish quality. Mar.Fish.Rev.43, 28.

Joseph D and D. Bronzino, (1995). The biomedical engineering hand book. CRC press, Inc IEEE press, 1385-1393.

Irimajiri A., K. Asami, T. Ichinowatari, and Y. Kinoshita, (1987). Passive electrical properties of the membrane and cytoplasm of cultured rat basophil leuemia cells, 1 . Dielectric behavior of cell suspensions in 0.01-500 $\mathrm{MHz}$ and its simulation with a single shell model" Biiochimicaet Biophysica Acta, 896,203-213.

Mohsenin, N.N. (1986). Physical Properties of Plant and Animal Materials. Gordon and Breach Science Publishes. New York, USA. Nelson S.O, and A.K. Datta. (2001). Dielectric properties of food material and electric field interactions. In Datta AK. Anantheswaran RC, editors. Handbook of Microwave technology for food applications. 
New York: Marcel Dekker Inc. P69-114.

Nelson S.O. W.R. Forbus, and K.C. Lawrence, (1995). Assessment of microwave permittivity for sensing peach maturity, Trans. of ASAE, 38: (2), 579-585.

Polk, C. and E. Postow, (1996). Hand book of biological effects of electromagnetic fields. second edition, CRC press, Inc. New York.

Sakaguchi, M. and A. Koike.(1992). Freshness assessment of fish fillets using the torrymeter and K-value.(Huss H.H. et al, (eds.)), Quality Assurance in the Fish Industry, Elsevier Science publishers. B.V 333-339.

Saltiel, C. and AK.Datta, (1999). Heat and mass transfer in microwave processing. Adv Heat Transfer 33:1-94.

\section{الملخص العربي}

\section{الخواص الكهربية لدرنات البطاطس والمرتبطة بظروف التخزين.

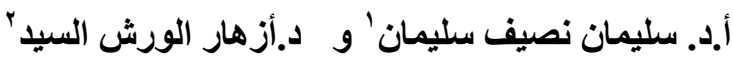

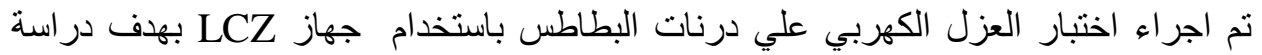

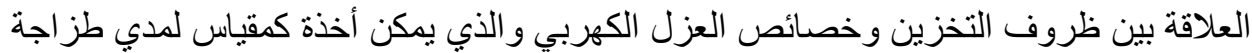

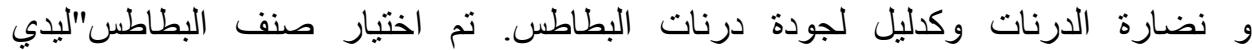
روزيتا"و الذي يتميزبكثافة نوعية ومادة جافة عالية ومحتوى سكري منخفض ويعتبر من أهم الأصناف لتصنيع رقائق الثييسى في مصر. تم قياس كل من السعوية (C,Farad) و التوصيلية (G, Siemens) كل من النفاذية (ee, farad/m) و الموصلية (ec, Siemens/m) و النفاذية النسبية ('eع) و و

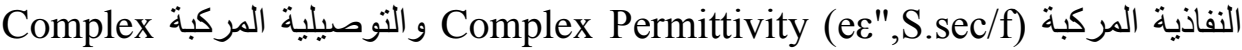
Conductivity e $\sigma ", f / m . s e c$ أوضحت النتائج ان اقصي سعوية (C, farad)عند ، الميلو هيرتز وتقل السعوية مع زيادة

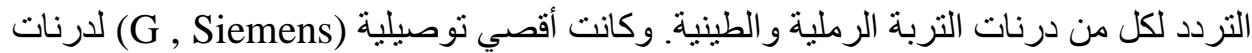
البطاطس عند . . . 1 كيلو هيرتز لمحصولي التربة الرية الرملية والطينية.

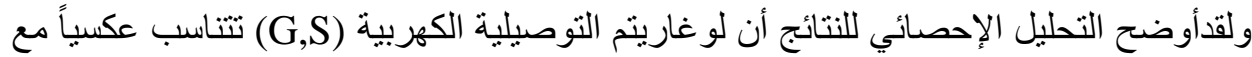

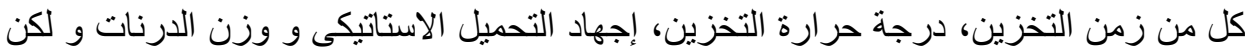
تنتاسب طرديا مع مستوي التردد.

1ـ أستاذ هندسة التصنيع الزراعي بقسم الهندسة الزراعية والنظم الحيوية ـ كلية الزراعة جامعة الإسكندرية. r r باحث بمعه بحوث الهندسة الزراعية ـ مركز البحوث الزراعية الدقي الجيزة. 


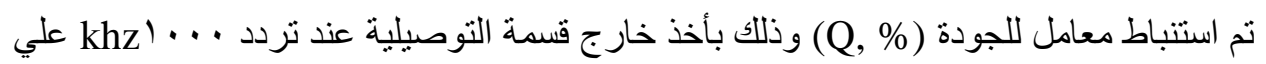

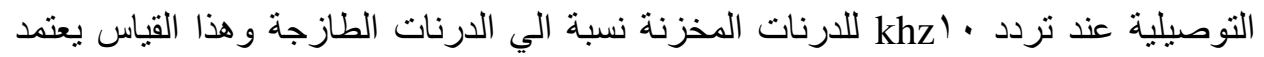

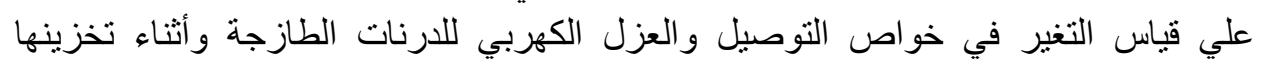

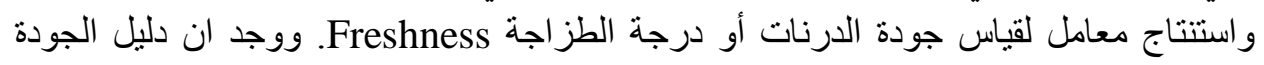
قيمنة تنتاسب طرديا مع درجة طز اجة الأنسجة.

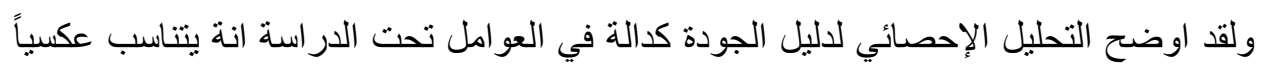

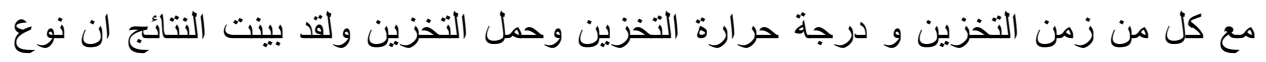

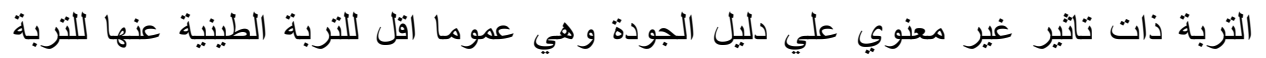

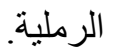

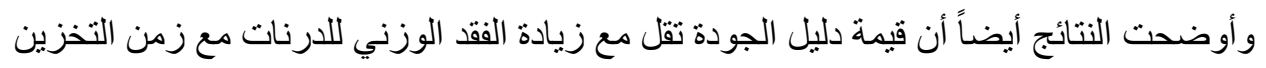

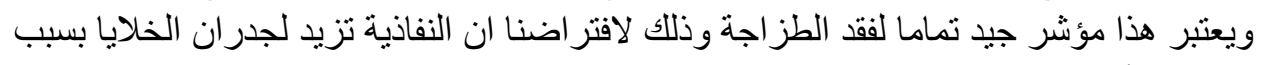

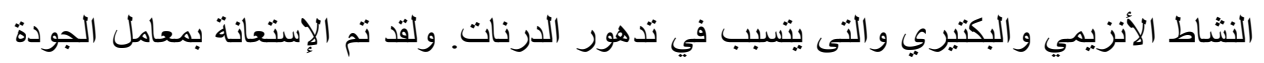

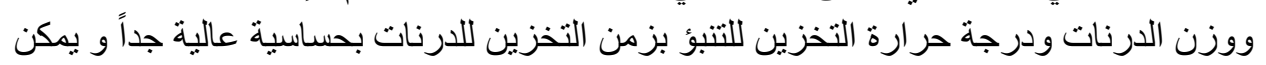
استخدامة علي المستوي التجاري لتحديد عمر التخزين لدرنات البطاطس. للترن الترن 